\title{
PERANCANGAN APLIKASI PERHITUNGAN HARGA POKOK PRODUKSI DENGAN METODE JOB ORDER COSTING PADA MEUDANG PERKASA FURNITURE
}

\author{
Muhammad Irzam Mulyanda*1, Evayani $^{* 2}$ \\ ${ }^{1,2}$ Program Studi Akuntansi Fakultas Ekonomi dan Bisnis Universitas Syiah Kuala \\ e-mail: mirzammulyanda@gmail.com ${ }^{* 1}$, eva_sahib@yahoo.com ${ }^{* 2}$
}

\begin{abstract}
The purpose of this research is to find out how the system of calculating the cost of goods manufactured that are currently running at Meudang Perkasa Furniture. This company is still calculating the cost of goods manufactured manually, which can lead to errors in the determination of costs incurred to produce goods. In addition, because the process is done manually, the calculation process takes a long time. This study aims to design an application that can help users to know the cost of goods manufactured quickly and precisely. The system designed in this study uses Microsoft Access. This study uses descriptive qualitative method, data collection techniques was done by conducting interviews, observations, and literature studies carried out directly with the owner of the company. This study resulted in a Cost of Goods Manufactured Application that would ease future corporate activities.
\end{abstract}

Keywords: Accounting Information System, Cost of Goods Manufactured, Job Order Costing, and Microsoft Access

\section{Pendahuluan}

Salah satu sistem yang menduduki peran penting terhadap jalannya suatu perusahaan yaitu Sistem Informasi Akuntansi (SIA). SIA ini berperan dalam menghimpun, mencatat, dan mengelola datadata yang terdapat di dalam transaksi akuntansi yang dikerjakan secara terus-menerus sehingga diperoleh informasi akuntansi dan keuangan (Romney \& Steinbart, 2014: 3).

Salah satu manfaat yang bisa didapatkan dari SIA adalah untuk memperkirakan beban-beban ataupun biaya yang dipakai untuk memproduksi suatu barang atau biasa disebut harga pokok produksi. Harga pokok produksi adalah biaya barang yang berupa biaya bahan baku, biaya tenaga kerja dan biaya overhead pabrik yang melalui tahap pemrosesan hingga tahap selesai, baik sebelum maupun saat berjalannya periode akuntansi (Horngren, 2008: 45).

Harga pokok produksi menjadi salah satu faktor penting untuk mempertimbangkan harga jual yang nantinya akan diakumulasikan dengan laba yang ingin diperoleh. Namun pada umumnya, perusahaan dalam menentukan harga jualnya belum memiliki kemampuan untuk mengukur biaya yang dikeluarkan secara tepat ketika melakukan produksi. Perusahaan hanya melakukan perhitungan kasar atas biaya produksinya kemudian ditambah dengan besaran keuntungan yang diharapkan untuk mendapatkan harga jual. Penentuan harga jual secara kasar ini mungkin masih bisa diterapkan untuk lingkungan industri yang kurang kompetitif. Namun untuk memasuki lingkungan industri yang kompetitif diperlukan manajemen yang baik. Dengan demikian, perhitungan harga jual secara kasar tidak efektif lagi untuk digunakan jika ingin memenangkan persaingan, maka diperlukan perancangan sebuah sistem terkomputerisasi yang berguna untuk memperhitungkan dan menentukan harga jual secara cepat dan tepat.

Salah satu perangkat lunak basis data yang dapat merancang sistem untuk melakukan proses perhitungan harga pokok produksi adalah Microsoft Access. Microsoft Access yang merupakan software untuk mengelola basis data model relasional sangat berguna untuk mengelola data-data secara terintegrasi, baik yang tergolong basis data sederhana maupun basis data yang kompleks (Nahlah \& Amirudin, 2015). Namun untuk melakukan perhitungan menggunakan sistem tersebut dibutuhkan suatu metode. Untuk itu penulis menggunakan metode harga pokok pesanan (Job Order Costing).

Metode harga pokok yang menurut pesanan ini adalah sebuah metode untuk menentukan harga pokok produksi di mana semua beban dan biaya produksi 
dihimpun menurut suatu pesanan yang spesifik dan harga pokok produksi untuk masing-masing produk tersebut dihitung menggunakan pembagian total biaya produksi untuk pesanan spesifik tersebut dengan total unit produk terhadap produk tersebut (Mulyadi, 2015: $35)$.

Perusahaan Meudang Perkasa yang berada di Jalan Teuku Iskandar, Kel. Lambhuk, Kec. Ulee Kareng, Banda Aceh merupakan perusahaan yang bergerak dibidang pembuatan segala macam furnitur berbahan kayu, seperti kursi, meja, pintu, lemari dsb. Pencatatan dan pendataan untuk semua kegiatan usaha selama ini masih menggunakan cara-cara manual. Pencatatan secara manual tersebut menyebabkan timbulnya kesulitan ketika ingin mencari data, data tidak tepat, dan juga kurang detail, bahkan terkadang tidak adanya pencatatan sehingga hal itu menyebabkan pengelola dan pemilik menghadapi kesulitan ketika ingin mengetahui harga pokok produksi untuk suatu produk.

Perhitungan harga pokok produksi yang berjalan saat ini juga menyulitkan akibat kebutuhan untuk suatu perabot selalu berbeda-beda antara satu perabot dengan perabot lain. Adanya perbedaan kebutuhan pelanggan mengakibatkan penetapan harga jualnya pun tidak dapat dipastikan setiap saat (Sofian \& Tumiran, 2015).

Berdasarkan masalah-masalah yang telah dijelaskan, perusahaan ini tentunya membutuhkan suatu sistem informasi akuntansi untuk mempermudah perusahaan dalam menghasilkan laporan. Salah satu penggunaan informasi yang tergolong penting bagi suatu organisasi atau perusahaan yaitu informasi tentang harga pokok produksi dalam memproduksi suatu produk yang ingin dijual, dimana perusahaan dapat mengetahui biaya-biaya atau ongkos yang dikorbankan dalam proses produksi serta mengetahui laba yang diperolah (Handojo et al., 2013).

Dengan adanya suatu sistem yang dapat menghasilkan informasi harga pokok produksi, karyawan yang ada tidak perlu lagi mencatat secara manual, karyawan hanya perlu meng-input data biayabiaya kedalam sistem. Data-data yang telah diolah ini nantinya akan menghasilkan laporan harga pokok produksi. Hal ini tentunya akan mempermudah pengelola untuk menetapkan harga pokok produksi yang selanjutnya ditetapkan pula keuntungan yang ingin diperoleh guna mendapatkan harga jual.

\section{Kajian Pustaka dan Kerangka Pemikiran Sistem}

Sistem merupakan kumpulan dari unsur-unsur yang saling berinteraksi serta saling terpaut satu sama lain (Sutabri, 2012: 3). Sistem ini dirancang berdasarkan pola tertentu yang saling berkaitan guna memaksimalkan kinerja serta mencapai tujuan yang diinginkan.

\section{Informasi}

Menurut Davis (2013: 16) informasi merupakan suatu data yang telah diproses, pemrosesan tersebut dimaksudkan agar data ini menjadi suatu hal yang lebih memiliki arti serta berguna bagi pemakainya untuk pengambilan keputusan di masa sekarang ataupun masa depan.

\section{Sistem Informasi}

Menurut Diana \& Setiawati (2011: 4) sistem pengolahan data atau yang biasa disebut sistem informasi, merupakan sistem yang dirancang manusia dan terdapat beberapa elemen (baik manual maupun terkomputerisasi) yang saling terintegrasi untuk menyatukan, menyimpan dan mengolah data serta memberikan informasi.

\section{Sistem Informasi Akuntansi (SIA)}

Sistem Informasi Akuntansi (SIA) adalah gabungan dari beragam komponen sumber daya, seperti manusia serta alat yang dibuat guna mengonversi data mengenai keuangan dan data lainnya menjadi suatu informasi yang bernilai guna bagi pemakainya (Bodnar \& Hopwood, 2010: 3). Sistem informasi akuntansi adalah sebuah turunan dari sistem informasi manajemen yang memiliki tujuan untuk menghasilkan informasi mengenai akuntansi dan keuangan selayaknya informasi lain yang didapatkan dari proses rutin transaksi akuntansi (Rama \& Jones, 2008: 6).

\section{Aplikasi}

Menurut Winarno, Zaki, \& SmithDev (2014: 12) aplikasi merupakan suatu komponen yang mempunyai kegunaan sebagai alat untuk menjalankan pemrosesan data dan bermacam-macam kegiatan lainnya seperti pengerjaan ataupun pengolahan dokumen dan file. 
Santoso (2010: 8) juga menjelaskan bahwa aplikasi adalah suatu kelompok file (form, class, report) yang berguna untuk melaksanakan suatu kegiatan tertentu yang saling berkaitan, misalnya aplikasi penggajian, aplikasi aset tetap, dll.

\section{Harga Pokok Produksi}

Harga pokok produksi adalah segala biaya yang berkaitan dengan barang ataupun produk yang didapatkan, yang terdiri biaya bahan baku, biaya tenaga kerja langsung, dan biaya overhead pabrik (Nafarin, 2009: 497). Kartadinata (2008: 38) juga menjelaskan bahwa definisi dari harga pokok produksi yaitu seluruh biaya dan pengeluaran yang harus dikorbankan untuk menghasilkan barang jadi.

\section{Metode Harga Pokok Pesanan}

Menurut Mulyadi (2015: 35) metode harga pokok pesanan merupakan sebuah metode untuk menghimpun biaya-biaya yang dikorbankan untuk memproduksi suatu pesanan dan harga pokok produksi untuk masing-masing unit dihitung dengan membagi jumlah keseluruhan biaya produksi pesanan tersebut dengan jumlah unit produk dalam pesanan tersebut. Carter \& Usry (2009: 114) juga menjelaskan bahwa metode harga pokok pesanan merupakan perhitungan biaya produk pesanan yang menggabungkan biaya bahan baku langsung, tenaga kerja langsung, dan overhead yang dibebankan ke setiap pesanan.

\section{Microsoft Access}

Menurut Suarna (2008: 11), Microsoft Access adalah suatu program aplikasi untuk mengelola basis data model relasional, karena terdiri dari lajur kolom dan lajur baris. Program ini juga merupakan suatu program yang familia dan dapat dimanfaatkan untuk merancang suatu sistem manajemen pencatatan dengan berbagai fasilitas yang tersedia.

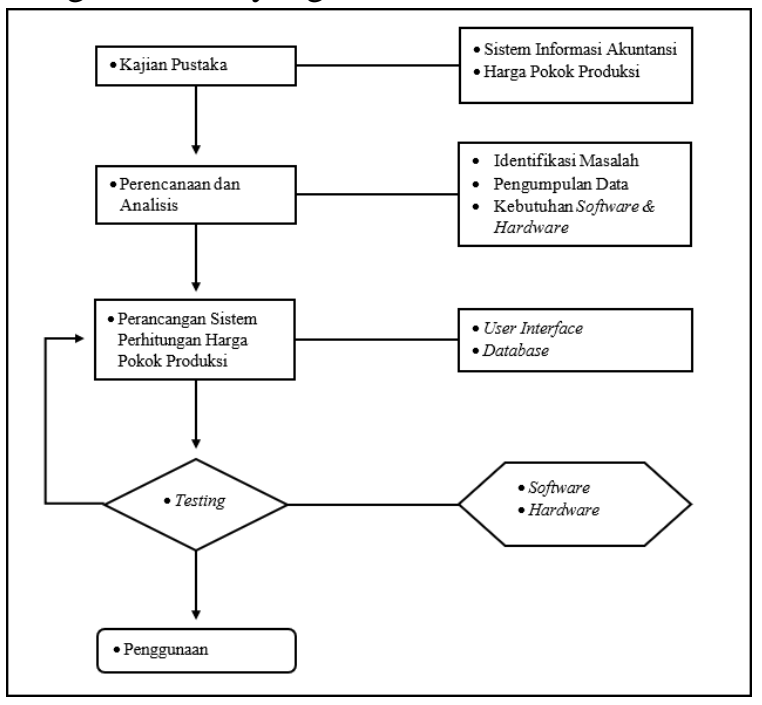

Gambar 2.1. Kerangka Pemikiran

\section{Metode Penelitian Desain Penelitian}

Tujuan studi dalam penelitian ini adalah deskriptif. Jenis investigasi pada penelitian ini menggunakan jenis penelitian studi eksperimental dimana peneliti harus melakukan tiga hal utama yaitu kegiatan mengontrol, memanipulasi, dan observasi yang bertujuan untuk mengetahui akibat manipulasi terhadap perilaku objek yang diamati. Situasi penelitian ini adalah tidak diatur. Unit analisis dalam penelitian ini adalah perusahaan yang merupakan Meudang Perkasa Furniture. Data yang dikumpulkan yaitu berupa data primer dan data sekunder. Horizon waktu dalam Gamebiaiaz. IniKedłahgk acPonsilsie anional.

\section{Sumber dan Teknik Pengumpulan Data}

Sumber data yang terdapat pada penelitian ini adalah data primer dan sekunder. Data primer yaitu wawancara serta observasi dan data sekunder berbentuk data dokumentasi, seperti faktur penjualan. Teknik pengumpulan data dilakukan dengan cara penelitian langsung ke lapangan serta studi pustaka.

\section{Proses Rencana Penelitian Studi Pustaka}

Pada tahap ini dikumpulkan berbagai teori acuan yang berasal dari bahan pustaka yang menjelaskan mengenai aplikasi perhitungan harga pokok produksi.

\section{Perencanaan dan Analisis}

Pada tahapan perencanaan dilakukan pengembangan aplikasi perhitungan harga pokok produksi pada Meudang Perkasa Furniture. Pada tahap ini dikumpulkan berbagai data hingga didapatkan masalah yang terjadi pada perusahaan tersebut. Permasalahan yang didapati diantaranya adalah belum terdapatnya suatu sistem untuk mengerjakan perhitungan harga pokok produksi yang dapat membantu Meudang Perkasa Furniture, belum tersedianya basis data untuk menyimpan dan mengelola data sehingga terdapat kesulitan dalam menampilkan informasi yang relevan dan terperinci. 


\section{Perancangan}

Pada proses ini merancang sebuah konsep diagram alir data dan diagram konteks. Kemudian dilakukan perancangan fisik yang berupa perancangan output. Perancangan ini akan menetapkan bentuk serta isi dari laporan yang dihasilkan.

\section{Pengujian}

Tahap pengujian merupakan tahapan yang dikerjakan setelah sistem selesai dirancang. Tahapan ini berhubungan dengan pemrograman, instalasi, dan rencana pemeliharaan. Pada tahapan ini juga dilakukan uji coba dan pelatihan yang bertujuan mengoptimalkan pemakaian sistem agar dapat digunakan sesuai dengan tujuan.

\section{Penggunaan}

Langkah terakhir merupakan tahap dimana sistem yang sudah lulus pada tahapan uji coba mulai digunakan oleh penggunanya.

\section{Hasil dan Pembahasan}

\section{Profil Perusahaan}

Meudang Perkasa Furniture yang beralamat di Jalan Teuku Iskandar, Kel. Lambhuk, Kec. Ulee Kareng, Banda Aceh. Didirikan pada tahun 1997 dikelola oleh Bapak Saiful Bahri selaku Pemilik, Azhari selaku Bagian Keuangan dan Ridha Muhajir sebagai Penanggung Jawab Umum. Perusahaan ini memiliki karyawan sebanyak 20 orang yang terdiri dari 1 bagian keuangan, 1 penanggung jawab umum, 1 kasir, 10 pekerja tetap, 2 pekerja bagian cat, 3 pekerja harian lepas dan 2 bagian gudang. Dalam usahanya perusahaan ini bergerak di bidang produksi dan penjualan perabotan. Perabotan yang dijual pada umumnya baru akan diproduksi apabila adanya pesanan, dimana pesanan ini sendiri mempunyai spesifikasi yang diinginkan oleh pelanggan.

\section{Analisis Sistem dan Prosedur Secara Manual Proses Perhitungan Harga Pokok}

Setelah mengumpulkan data yang diperlukan melalui wawancara dan penelitian lapangan dengan pemilik perusahaan, didapatkan tahapan-tahapan yang sedang berjalan dalam menentukan harga jual. Berikut adalah analisis tahapan yang telah berjalan pada perusahaan.

1) Pelanggan memesan produk yang diinginkan kepada kasir beserta dengan spesifikasinya

2) Kasir mencatat pesanan dan memberikan gambaran mengenai pesanan yang diinginkan pelanggan

3) Kasir memberikan catatan spesifikasi pesanan kepada penanggung jawab umum

4) Penanggung jawab umum menerima catatan spesifikasi pesanan untuk diteruskan ke bagian gudang

5) Gudang menerima catatan spesifikasi pesanan dan mengecek ketersediaan bahan baku

6) Gudang mencatat bahan baku apa saja yang diperlukan beserta spesifikasinya untuk memproduksi produk tersebut

7) Penanggung jawab umum menerima catatan mengenai spesifikasi bahan baku yang diperlukan untuk diteruskan kepada bagian keuangan

8) Bagian keuangan menghitung berapa biaya yang harus dikeluarkan berdasarkan catatan mengenai kebutuhan bahan baku

9) Bagian keuangan menambahkan berapa biaya tenaga kerja yang dikeluarkan ke dalam unsur harga pokoknya

10) Kasir menerima catatan mengenai harga pokok yang telah dihitung oleh bagian keuangan

11) Kasir menambahkan jumlah keuntungan yang ingin diperoleh lalu mendapatkan harga jual untuk diberikan kepada pelanggan

\section{Diagram Konteks}

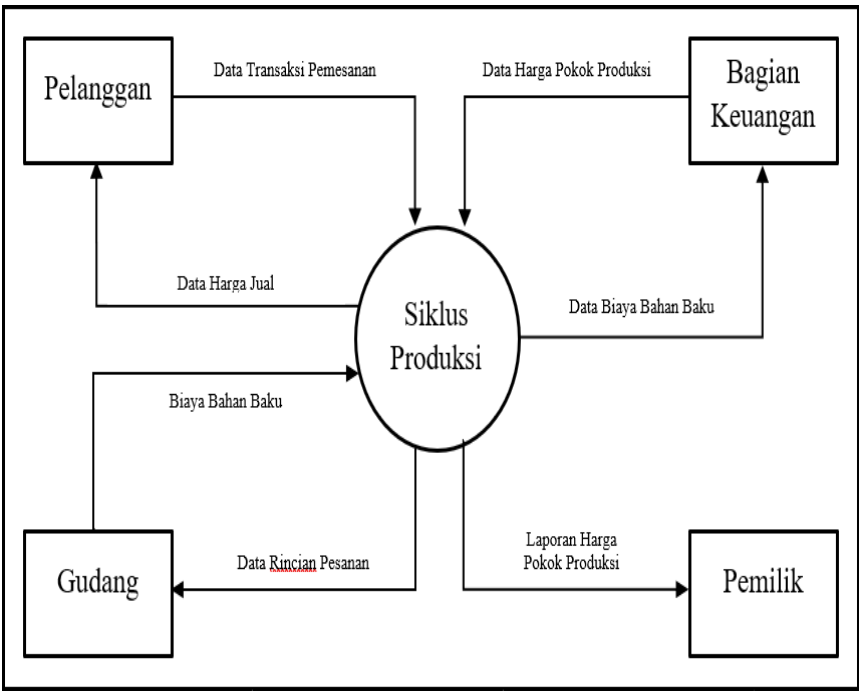




\section{Diagram Nol}

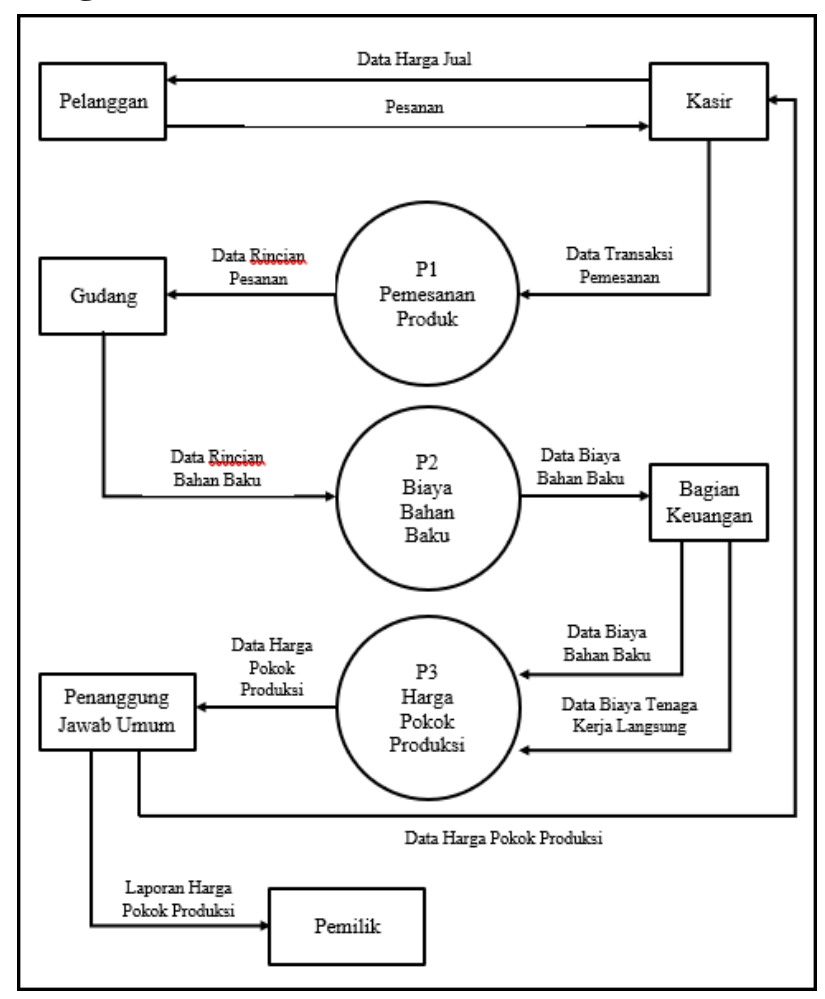

Evaluasi Sistem Berjalan

\begin{tabular}{|c|l|l|}
\hline No. & \multicolumn{1}{|c|}{ Permasalahan } & \multicolumn{1}{c|}{ Solusi/Rencana } \\
\hline 1 & $\begin{array}{l}\text { Proses perhitungan harga pokok } \\
\text { produksi masih sering mengalami } \\
\text { kesalahan }\end{array}$ & $\begin{array}{l}\text { Penerapan sistem informasi yang } \\
\text { bisa mempermudah perhitungan } \\
\text { harga pokok produksi }\end{array}$ \\
\hline 2 & $\begin{array}{l}\text { Proses perhitungan bahan baku yang } \\
\text { belum terlalu akurat karena } \\
\text { pencatatannya masih dilakukan } \\
\text { secara manual }\end{array}$ & $\begin{array}{l}\text { Perhitungan bahan bakunya akan } \\
\text { lebih akurat karena langsung di- } \\
\text { input ke dalam sistem informasi }\end{array}$ \\
\hline 3 & $\begin{array}{l}\text { Tidak terjaminnya keamanan data } \\
\text { jika ingin dikelola }\end{array}$ & $\begin{array}{l}\text { Terjaminnya keamanan data yang } \\
\text { telah ada menjadi lebih baik dengan } \\
\text { adanya sistem informasi }\end{array}$ \\
\hline 4 & $\begin{array}{l}\text { Laporan mengenai biaya pokok } \\
\text { produksinya tidak terlalu akurat } \\
\text { oleh karena tidak memasukkan } \\
\text { unsur biaya beban pabrik }\end{array}$ & $\begin{array}{l}\text { Dengan diterapkannya sistem } \\
\text { informasi, laporan biaya pokok } \\
\text { produksinya akan lebih akurat } \\
\text { karena sudah dimasukkan biaya } \\
\text { beban pabrik }\end{array}$ \\
\hline
\end{tabular}

\section{Analisis Kebutuhan Sistem Informasi Usulan}

Informasi merupakan bagian dari sistem yang berperan besar terhadap perusahaan. Keunggulan suatu sistem informasi dapat dinilai berdasarkan seberapa akurat dan seberapa tepat informasi yang dihasilkan. Setelah dilakukan analisis terhadap sistem terdahulu dan mendapatkan permasalahan yang terjadi di dalam perusahaan, maka diperlukan solusi untuk mengatasi masalah ini yaitu dengan pembuatan sistem informasi secara terkomputerisasi menggunakan perangkat lunak Microsoft Access pada sistem perhitungan harga pokok produksi Meudang Perkasa. Suatu sistem yang dapat mempermudah penggunanya untuk menghitung harga pokok produksi yang dikeluarkan secara terkomputerisasi.

\section{Analisis Data}

Meudang Perkasa memiliki permasalahan dalam penyimpanan, pengolahan serta penyajian datanya. Penyimpanan dan pengolahan datanya masih dilakukan secara manual karena hanya menggunakan kertas atau buku sebagai media utamanya yang bersifat rentan akan kerusakan serta mudah kehilangan.

Pada sistem yang berjalan saat ini, ketika perusahaan ingin mengetahui informasi mengenai bahan baku, pesanan dan juga perhitungan biaya pokok produksi masih menghadapi masalah dalam menemukan informasinya dan membutuhkan waktu yang lama, karena harus membuka dan membolakbalik setiap arsip dan kertas-kertas file yang menyimpan mengenai data-data tersebut. Oleh karena itu, perusahaan membutuhkan suatu sistem informasi yang dapat mengakses data secara cepat dan mudah melalui setiap media dialog dalam bentuk tampilan layar.

\section{Analisis Penyimpanan Data}

Penyimpanan data serta dokumen pada saat ini masih berupa kertas-kertas yang disatukan menjadi arsip dan juga masih menggunakan buku. Cara menyimpan data seperti itu mengakibatkan sulitnya mengakses data yang dibutuhkan sehingga memakan waktu yang cukup lama. Akibat dari itu, pihak perusahaan sering terhambat dalam penyajian informasi yang bersifat segera. Data pada sistem terdahulu tidak disimpan dalam sebuah basis data yang diprogram secara terkomputerisasi, oleh karena itu dari segi keamanan masih harus diperhatikan 
masalah penyimpanan data agar dapat dijaga dengan baik.

\section{Analisis Kebutuhan Sistem yang Diusulkan}

Menarik kesimpulan dari permasalahan yang terjadi di atas, maka Meudang Perkasa memerlukan suatu sistem informasi untuk menghitung biaya pokok produksi yang dikeluarkan secara terkomputerisasi. Sebuah sistem yang mudah dipahami oleh pengguna dalam menjalankan pekerjaannya dan berguna untuk menghemat waktu serta meminimalisir kesalahan yang bisa saja terjadi. Sistem informasi yang telah disebutkan meliputi beberapa hal, yaitu:

1) Membutuhkan konfigurasi penyimpanan data yang lebih baik agar dapat memudahkan bagian keuangan untuk menyimpan serta mengakses data secara cepat guna meminimalisir pemakaian waktu.

2) Mengotomatisasi perhitungan terhadap biaya pokok produksi yang dikeluarkan

3) Sistem yang dapat membantu mengendalikan bahan baku yang digunakan

4) Sistem yang dapat menghasilkan laporan yang berisi biaya yang dikeluarkan secara akurat dan tepat.

\section{Perancangan Sistem}

Setelah menganalisis sistem terdahulu perusahaan serta menemukan permasalahan apa saja yang terjadi pada sistem terdahulu maka penulis memberikan solusi berupa perancangan dan pembuatan suatu sistem informasi secara terkomputerisasi guna mendukung operasional perusahaan, khususnya dalam mengelola bahan baku serta menghitung biaya yang dikeluarkan terhadap produksinya.

\section{Diagram Konteks yang Diusulkan}

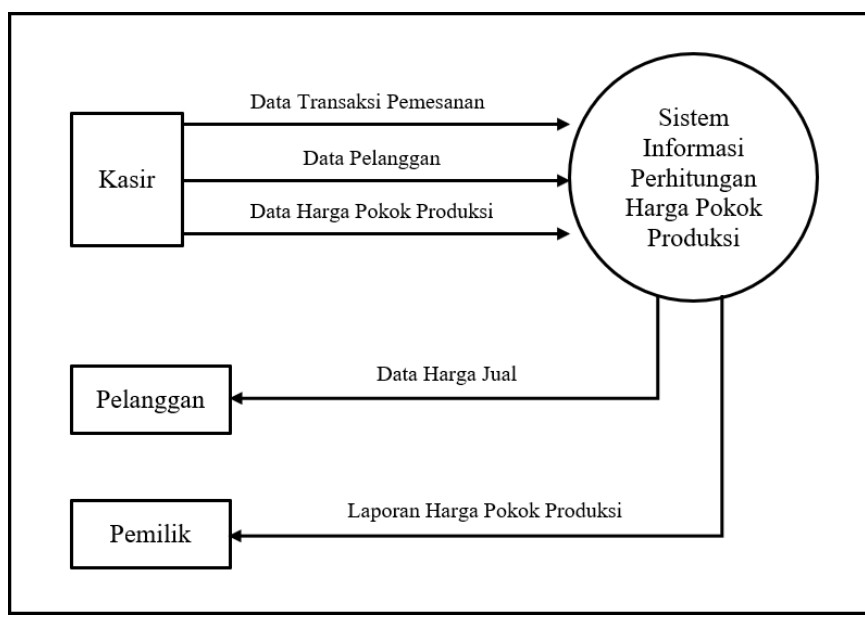

\section{Diagram Nol Sistem yang Diusulkan}

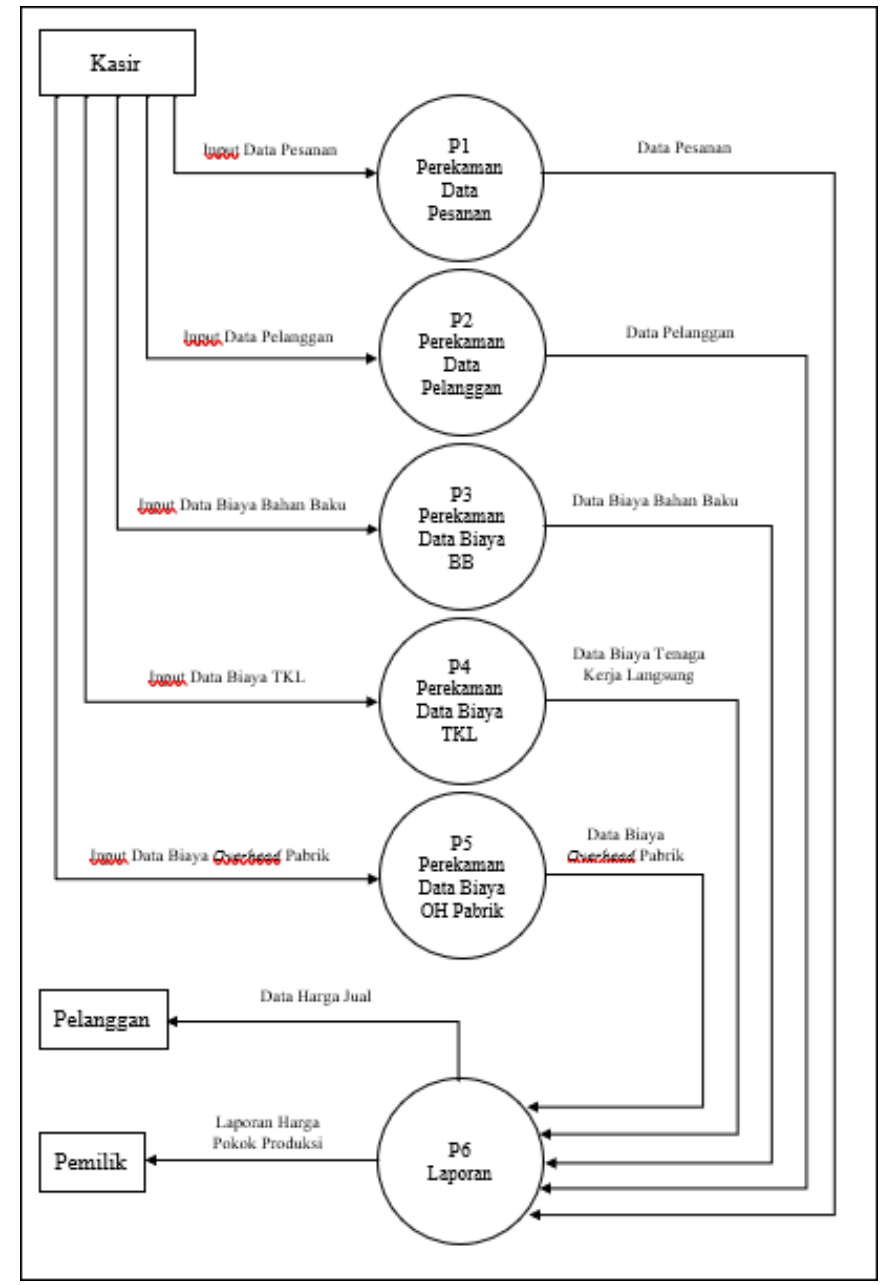

\section{Kamus Data dan Uraian Proses}

Kamus data (data dictionary) dapat diartikan sebagai data-data yang diperlukan untuk membuat ataupun membangun suatu sistem. Kamus data ini menjadi penghubung antar analisis sistem dengan 
perancang sistem. Kamus data ini menjadi alat komunikasi untuk mengetahui bentuk informasi apa yang dibutuhkan oleh pemakai sehingga dapat dirancang sistem yang tepat guna.

\section{Dokumen Masukan}

\section{Nama Proses: Menu Utama}

Tujuan: Menampilkan Halaman Utama Aplikasi

Keterangan: Halaman utama ini terdiri dari Form untuk memasukkan data serta menghasilkan Report yang merupakan laporan yang dibutuhkan.

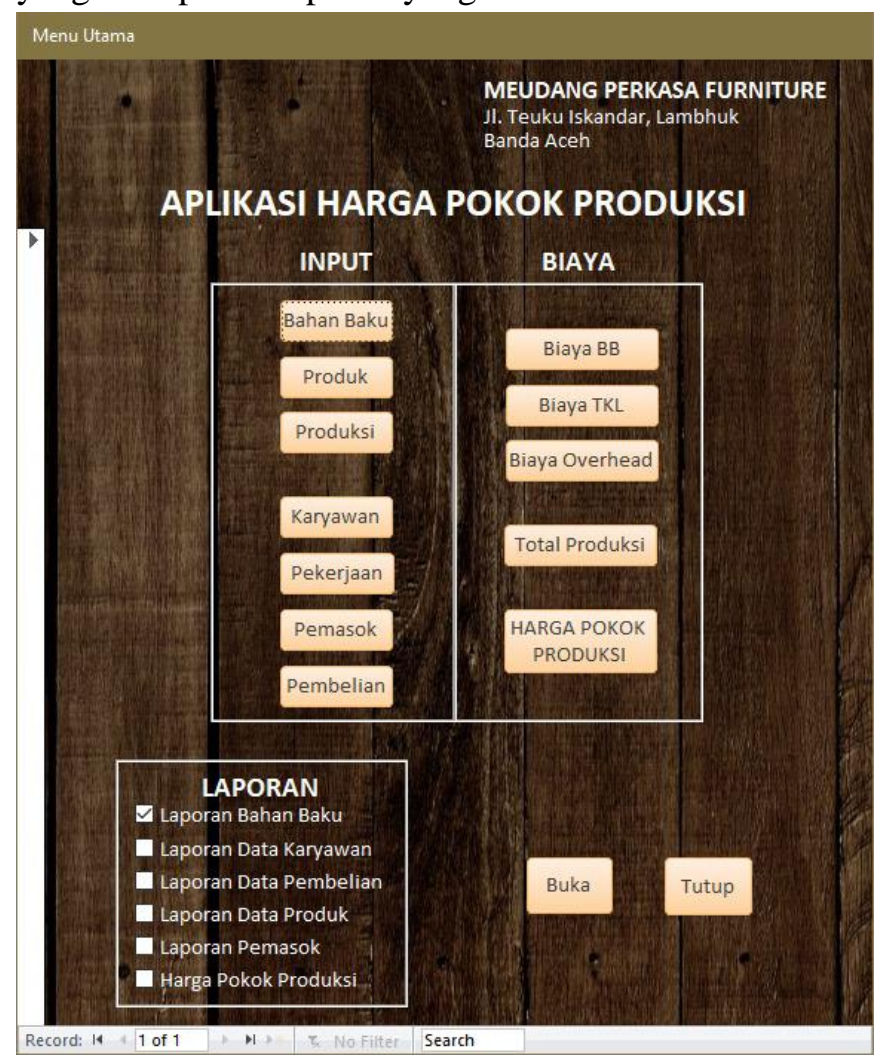

\section{Nama Proses: Form Input Bahan Baku}

Tujuan: Memasukkan data bahan baku

Penjelasan: Dengan menekan tombol "Bahan Baku" maka pengguna dapat memasukkan informasi mengenai bahan baku ke dalam tabel data bahan baku.

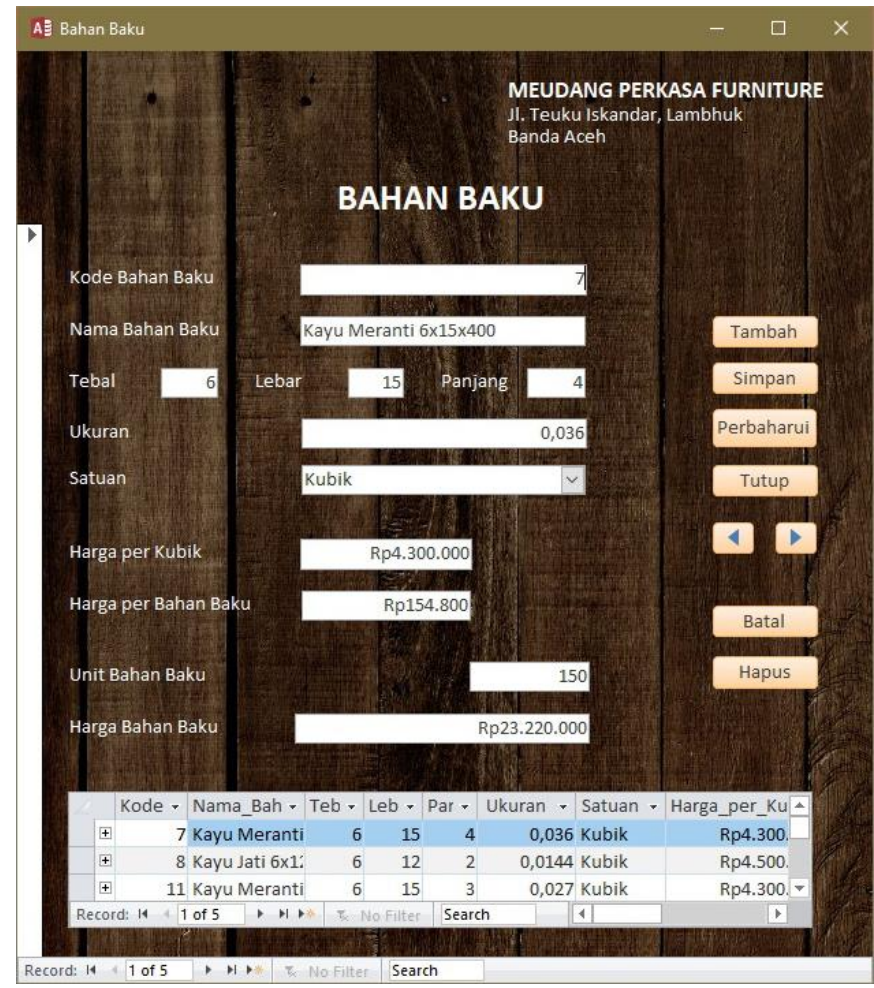

\section{Nama Proses: Form Input Produk}

Tujuan: Memasukkan data produk

Penjelasan: Dengan menekan tombol "Produk", pengguna dapat memasukkan informasi mengenai produk yang akan dibuat ke dalam tabel data produk

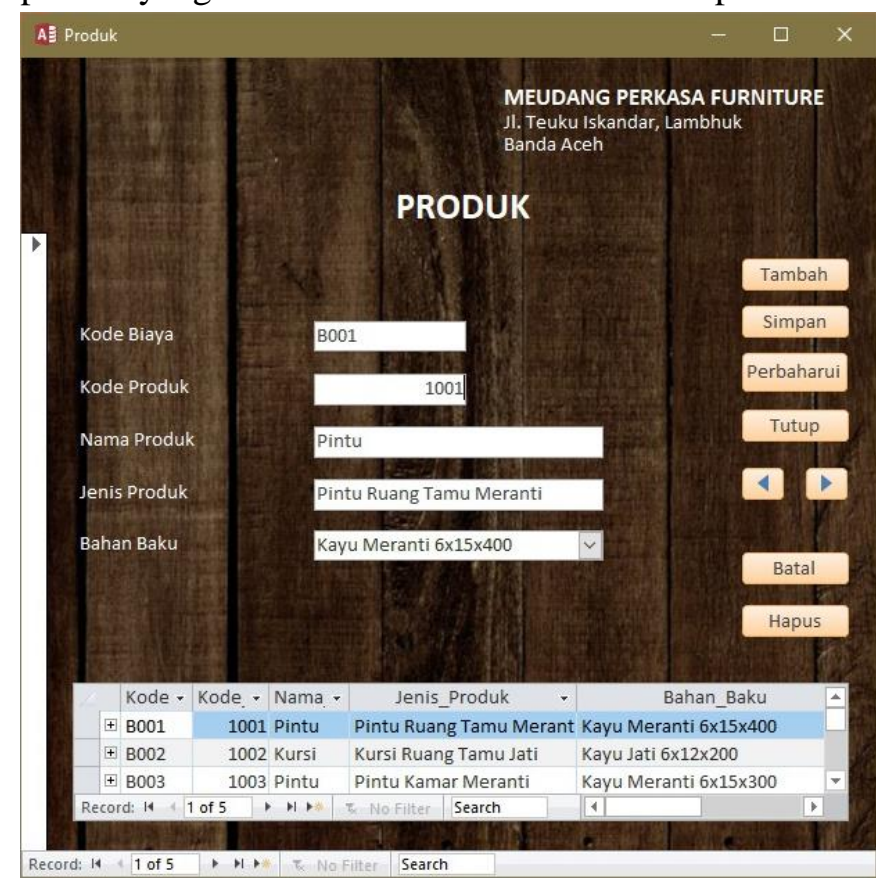

Nama Proses: Form Input Produksi 
Tujuan: Memasukkan data mengenai produksi

Penjelasan: Dengan menekan tombol "Produksi", maka pengguna dapat memasukkan informasi mengenai produk serta berapa jumlah unit produk yang akan diproduksi ke dalam tabel produksi.

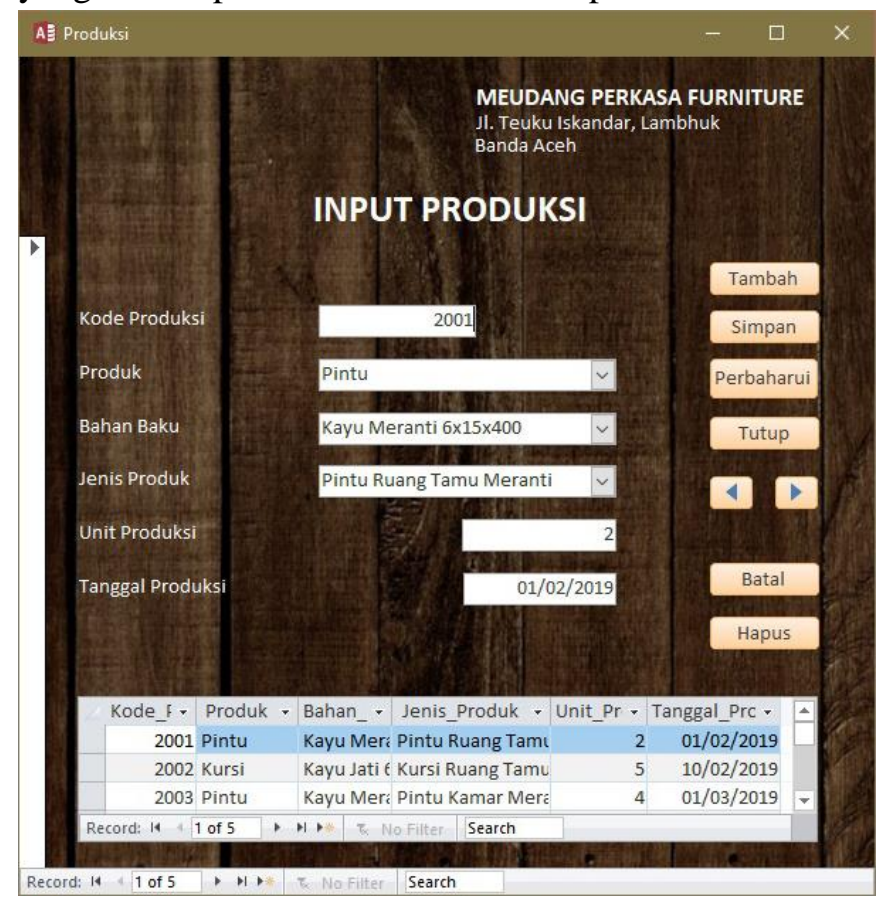

\section{Nama Proses: Form Input Data Karyawan}

Tujuan: Memasukkan data karyawan

Penjelasan: Dengan menekan tombol "Karyawan", pengguna dapat memasukkan informasi mengenai karyawan ke dalam tabel karyawan.

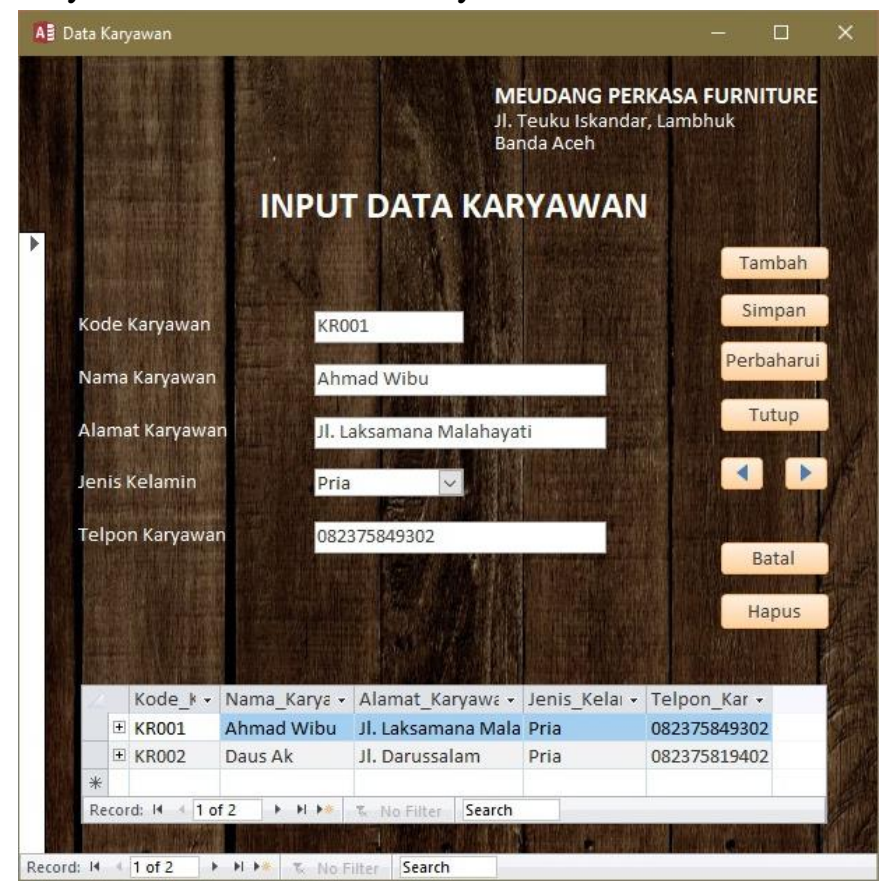

\section{Nama Proses: Form Input Pekerjaan}

Tujuan: Memasukkan data pekerjaan

Penjelasan: Dengan menekan tombol "Pekerjaan" maka pengguna dapat memasukkan informasi mengenai pekerjaan apa saja yang harus dilakukan serta berapa jumlah jam dan upah yang harus dikeluarkan.

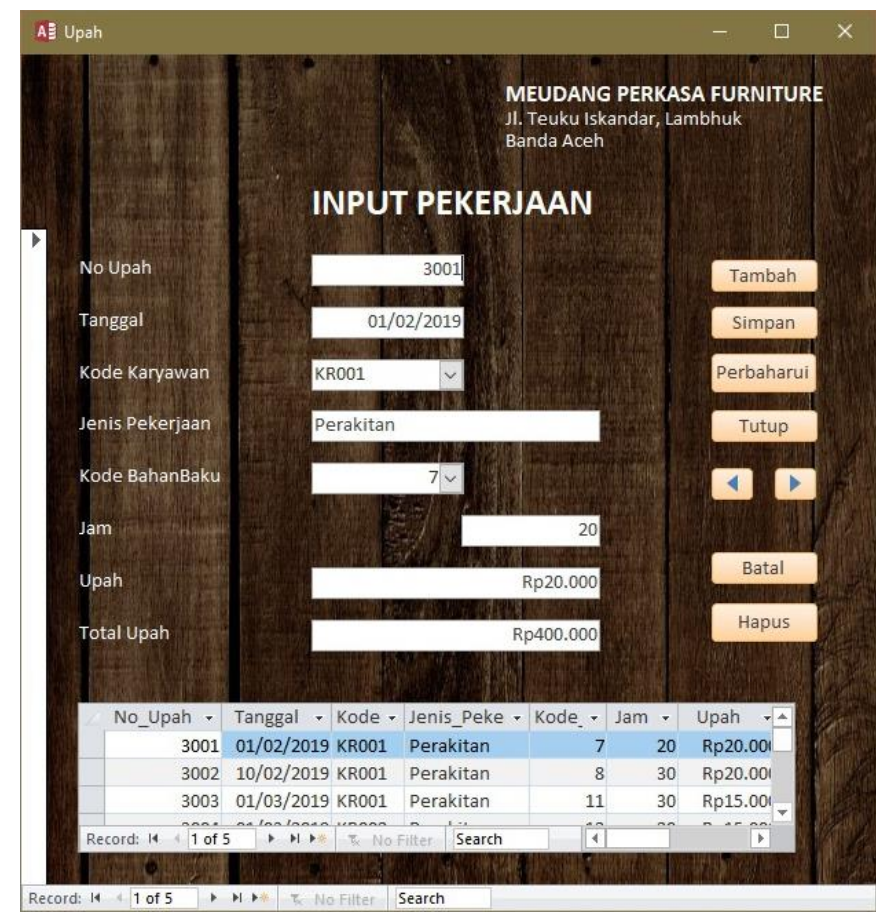

\section{Nama Proses: Form Input Data Pemasok}

Tujuan: Memasukkan data pemasok

Penjelasan: Dengan menekan tombol "Pemasok", pengguna dapat memasukkan informasi mengenai pemasok ke dalam tabel pemasok. 


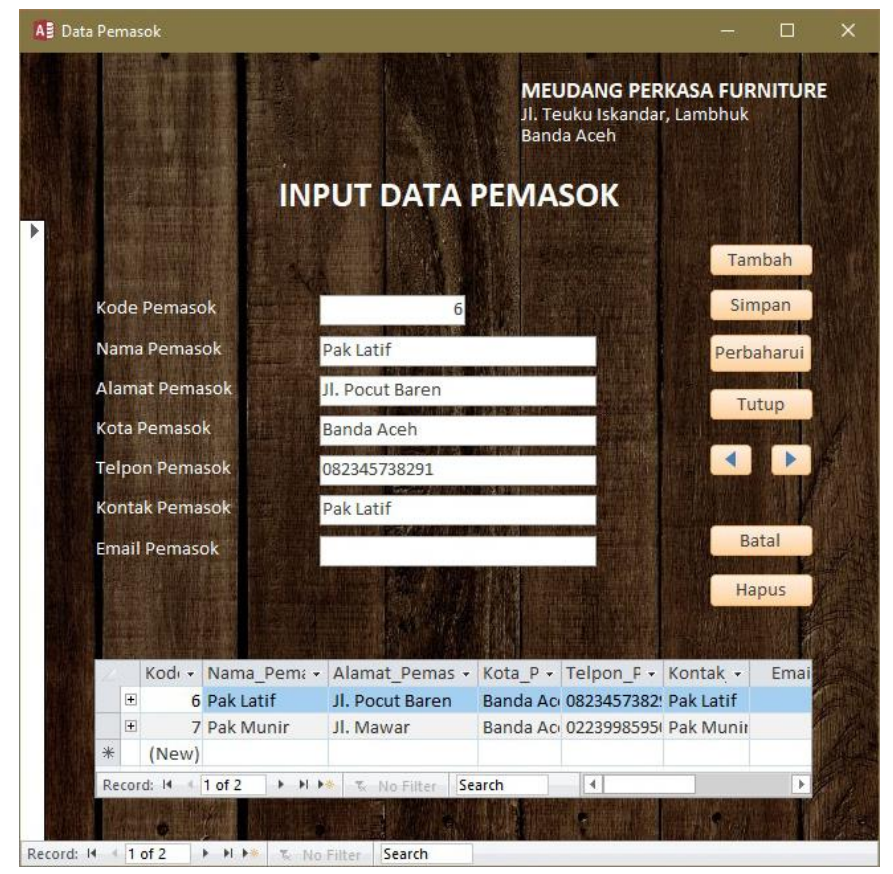

\section{Nama Proses: Form Input Pembelian}

Tujuan: Memasukkan data pembelian

Penjelasan: Dengan menekan tombol "Pembelian" maka pengguna dapat memasukkan informasi mengenai pembelian bahan baku dan siapa yang membelinya.

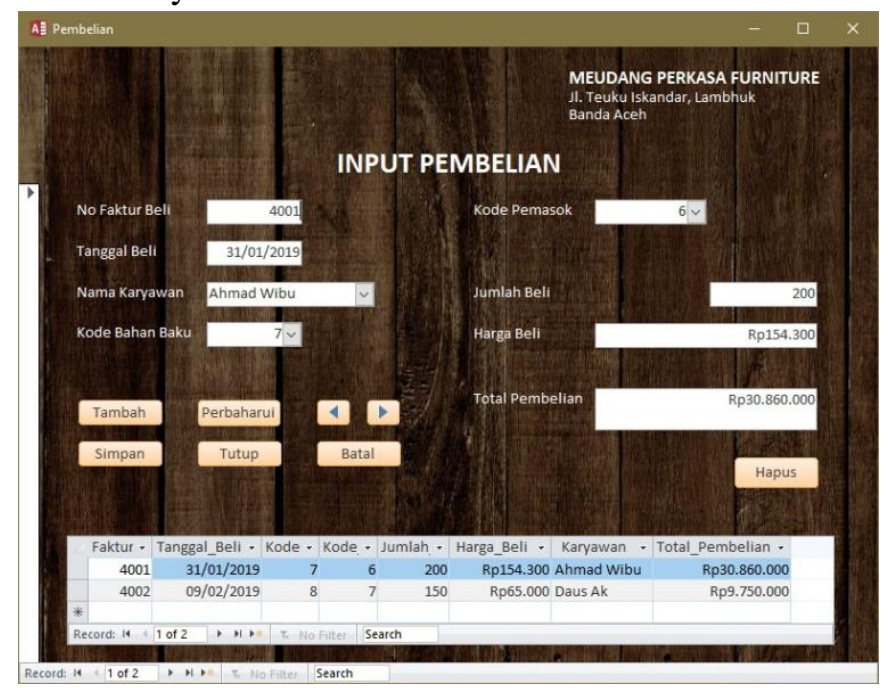

\section{Nama Proses: Form View Biaya Bahan Baku}

Tujuan: Melihat biaya bahan baku

Penjelasan: Dengan menekan tombol "Biaya Bahan Baku ", pengguna dapat melihat biaya bahan baku yang dikeluarkan untuk memproduksi suatu produk.

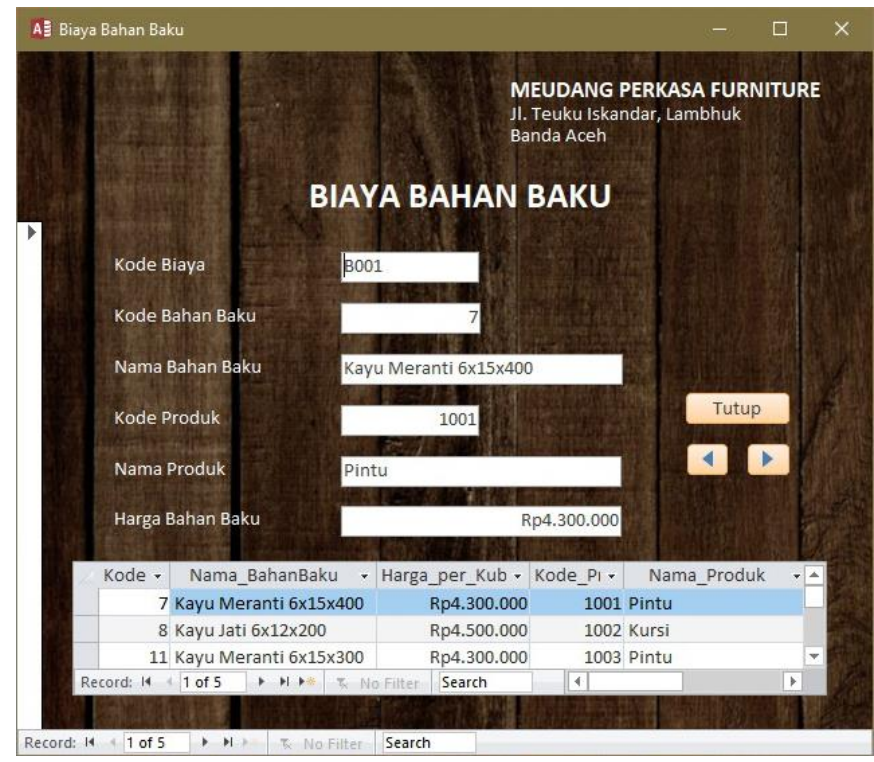

\section{Nama Proses: Form View Biaya Tenaga Kerja Langsung}

Tujuan: Memasukkan biaya tenaga kerja langsung Penjelasan: Dengan menekan tombol "Biaya Tenaga Kerja Langsung" maka pengguna dapat melihat biaya tenaga kerja langsung yang dikeluarkan untuk memproduksi suatu produk.

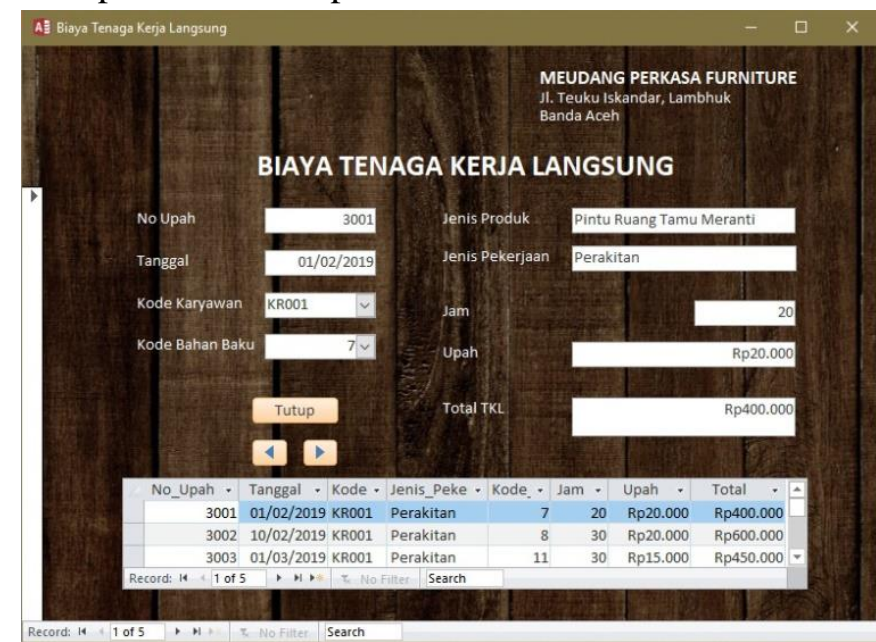

Nama Proses: Form Input Biaya Overhead Pabrik Tujuan: Memasukkan data biaya overhead pabrik Penjelasan: Dengan menekan tombol "Biaya Overhead", pengguna dapat memasukkan data-data mengenai biaya overhead apa saja yang harus dikeluarkan untuk memproduksi suatu barang. 


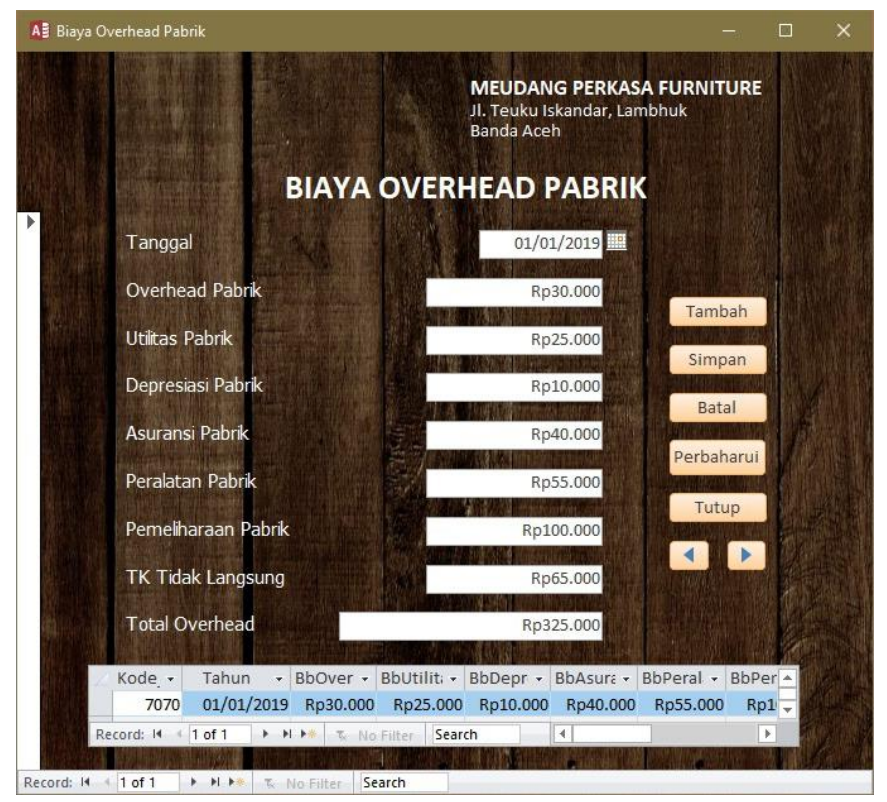

\section{Nama Proses: Form Total Biaya Produksi}

Tujuan: Melihat data total biaya produksi

Penjelasan: Dengan menekan tombol "Total Produksi", pengguna dapat melihat jumlah keseluruhan biaya produksi yang meliputi biaya bahan baku, biaya tenaga kerja langsung, serta biaya overhead yang harus dikeluarkan untuk memproduksi suatu produk.

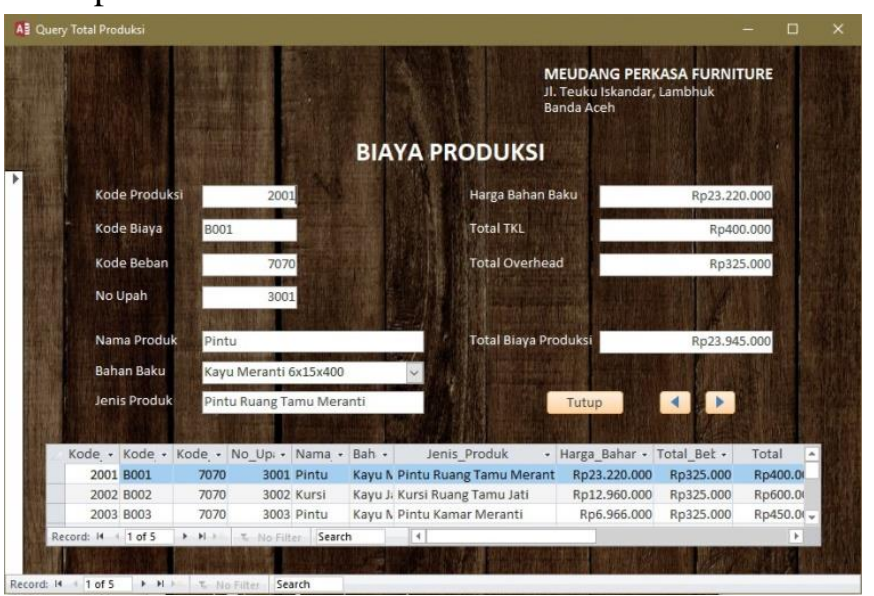

\section{Nama Proses: Form Harga Pokok Produksi}

Tujuan: Melihat harga pokok produksi

Penjelasan: Dengan menekan tombol "Harga Pokok Produksi", pengguna dapat melihat jumlah keseluruhan biaya produksi yang meliputi biaya bahan baku, biaya tenaga kerja langsung, serta biaya overhead yang harus dikeluarkan serta membaginya dengan jumlah unit yang diproduksi untuk mendapatkan Harga Pokok Produksi untuk masingmasing produk yang dihasilkan.

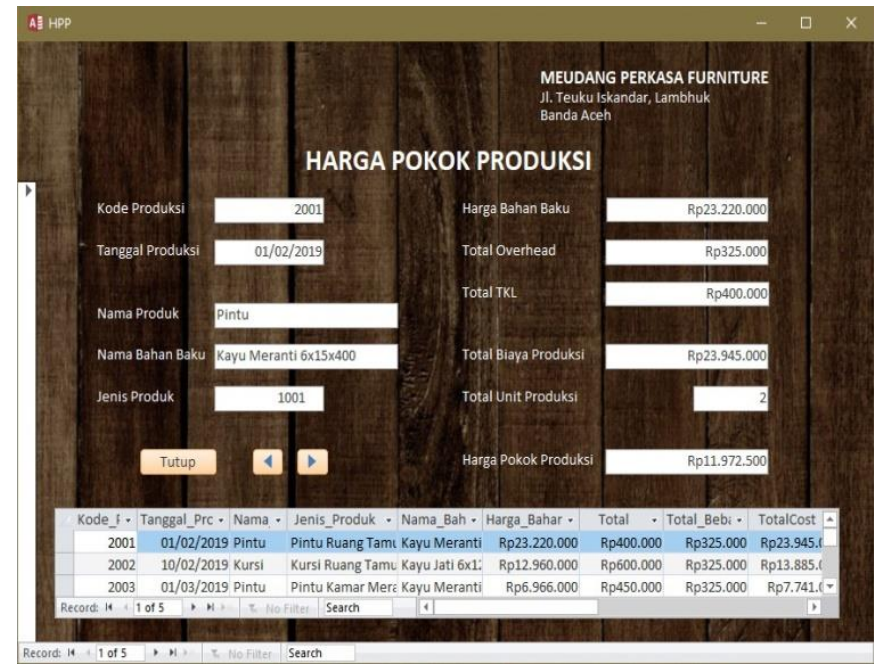

\section{Dokumen Keluaran}

\section{Nama Proses: Laporan Bahan Baku}

Tujuan: Menampilkan laporan bahan baku

Penjelasan: Dengan mencentang kotak "Laporan Bahan Baku" lalu menekan tombol "Buka", pengguna dapat melihat laporan yang berisi informasi mengenai bahan baku.

\begin{tabular}{|c|c|c|c|c|c|}
\hline \multicolumn{4}{|c|}{$\begin{array}{l}\text { MEUDANG PERKASA FURNITURE } \\
\text { II. Teuku Iskandar, Lambhuk } \\
\text { Banda Aceh }\end{array}$} & \multicolumn{2}{|c|}{ LAPORAN BAHAN BAKU } \\
\hline Kode & Nama & Ukuran & Satuan & Harga per Kubik & Harga per Bahan Baku \\
\hline 7 & Kayu Meranti $6 \times 15 \times 400$ & 0,036 & Kubik & Rp4. 300.000 & Rp154.800 \\
\hline 8 & Kayu Jati $6 \times 12 \times 200$ & 0,0144 & Kubik & Rp4.500.000 & Rp64.800 \\
\hline 11 & Kayu Meranti 6×15×300 & 0,027 & Kubik & Rp4.300.000 & Rp116.100 \\
\hline 12 & Kayu Seumantok $6 \times 12 \times 400$ & 0,0288 & Kubik & Rp6.000.000 & Rp 172.800 \\
\hline 13 & Kayu Jati $6 \times 30 \times 400$ & 0,072 & Kubik & Rp4.500.000 & Rp324.000 \\
\hline
\end{tabular}

Diketahui Oleh,

Selasa, 09 April 2019

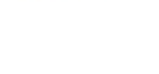
Dibuat Oleh,

\section{Nama Proses: Laporan Data Karyawan}

Tujuan: Menampilkan laporan data karyawan 
Penjelasan: Dengan mencentang kotak "Laporan Data Karyawan" lalu menekan tombol "Buka", pengguna dapat melihat laporan yang berisi informasi mengenai karyawan.

\begin{tabular}{|c|c|c|c|c|}
\hline \multicolumn{5}{|c|}{$\begin{array}{l}\text { MEUDANG PERKASA FURNITURE } \\
\text { Il. Teuku Iskandar, Lambhuk } \\
\text { Banda Aceh }\end{array}$} \\
\hline & & \multicolumn{3}{|c|}{ LAPORAN DATA KARYAWAN } \\
\hline Kode & Nama & Alamat & Jenis Kelamin & Telpon \\
\hline KROO1 & Ahmad Wibu & Jl. Laksamana Malahayati & Pria & 082375849302 \\
\hline KROO2 & Daus Ak & H. Darussalam & Pria & 082375819402 \\
\hline
\end{tabular}

Selasa, 09 April 2019 Dibuat Oleh.

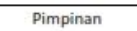

\section{Nama Proses: Laporan Data Pembelian}

Tujuan: Menampilkan laporan data pembelian

Penjelasan: Dengan mencentang kotak "Laporan Data Pembelian" lalu menekan tombol "Buka", pengguna dapat melihat laporan yang berisi informasi mengenai pembelian yang dilakukan karyawan.

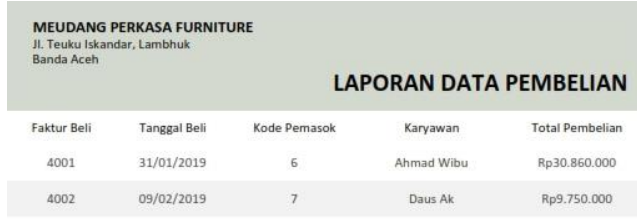

Diketahui Oleh.

\section{Nama Proses: Laporan Data Produk}

Tujuan: Menampilkan laporan data produk

Penjelasan: Dengan mencentang kotak "Laporan Data Produk" lalu menekan tombol "Buka", pengguna dapat melihat laporan yang berisi informasi mengenai produk yang diproduksi.

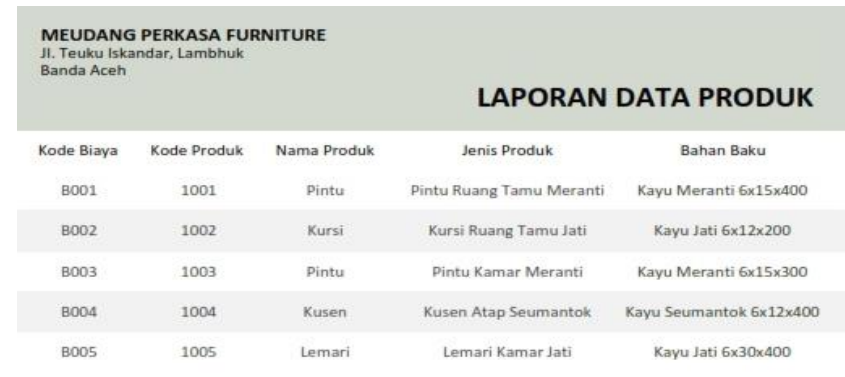

Nama Proses: Laporan Data Pemasok

Tujuan: Menampilkan laporan data pemasok 
Penjelasan: Dengan mencentang kotak "Laporan Data Pemasok" lalu menekan tombol "Buka", pengguna dapat melihat laporan yang berisi informasi mengenai pemasok.
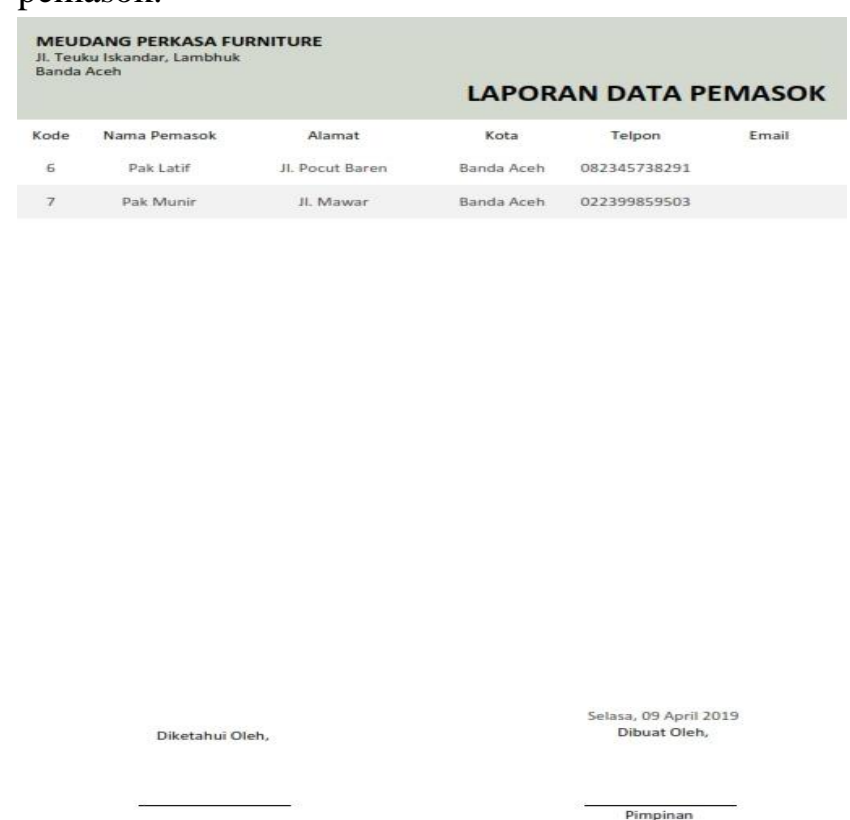

\section{Nama Proses: Laporan Harga Pokok Produksi}

Tujuan: Menampilkan laporan harga pokok produksi Penjelasan: Dengan mencentang kotak "Laporan Harga Pokok Produksi" lalu menekan tombol "Buka", pengguna dapat melihat laporan yang berisi informasi Harga Pokok Produksi.

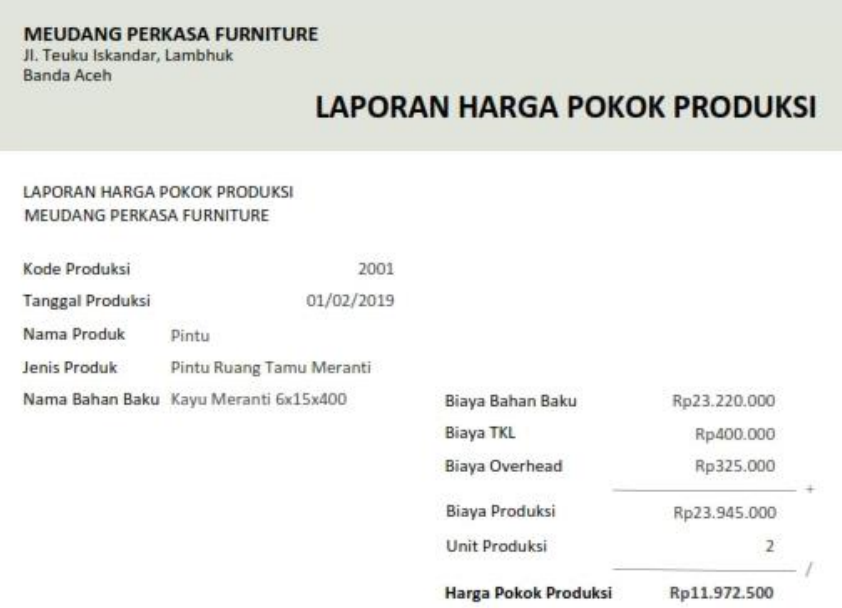

Diketahui Oleh,

Selasa, 09 April 201 Dibuat Oleh,

\section{Pengujian Sistem}

Pengujian pada Meudang Perkasa Furniture dilakukan dengan memasukkan data-data dan informasi. Informasi dimasukkan sesuai dengan yang sudah tertera pada sistem yaitu nama produk, jenis produk, nama bahan baku, biaya bahan baku, biaya tenaga kerja langsung, biaya overhead, total biaya produksi, jumlah unit yang diproduksi, dan harga pokok produksi.

\begin{tabular}{|c|c|c|c|c|c|c|c|c|}
\hline Kode - Tangeg & Jenis Produk & Nama_ & , & Total $\cdot$ & Total 18 & talcos & & HPP \\
\hline 2001 & Pinturua & i KayuN & & Reparo:000 & 0 Ro 035,000 & 000 & & Rep11972500 \\
\hline 2002 & Yuri & KapuJati $6 x 120200$ & 000 & Rpo600.00 & R R R 3 & $\mathrm{h}^{2}$ & & ( \\
\hline Pintu & Pintuk & 300 & & Rpos50:000 & O R R 325,000 & $07,741,000$ & & 801935.25 \\
\hline 2004 01/03/2019 Kusen & Kusen Aitio & Kapuseuman & m & Rpo300.00 & o $R$ & 1518 & 400 & Rp87.,563 \\
\hline $200509 / 03 / 20$ & Le & 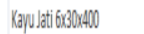 & v & Ro6000.00 & Ro Ro3. & mips:al, & & Re3.517 \\
\hline
\end{tabular}

Pengujian sistem ini menghasilkan Laporan Harga Pokok Produksi.

\section{Penggunaan Sistem}

Berdasarkan hasil pengujian, bisa diambil kesimpulan bahwa sistem aplikasi harga pokok produksi yang dapat berfungsi dengan baik pada 
perusahaan Meudang Perkasa Furniture. Sistem yang dirancang digunakan oleh pengguna yang terlibat di dalam bidang keuangan.

Ketika sistem baru ini diterapkan seluruh karyawan yang dapat diterima dengan baik, penerapan sistem pada perusahaan ini sangat membantu jalannya operasional perusahaan sehingga berdampak pada cara penetapan harga pokok produksi, dimana dalam menetapkan harga pokok produksi bisa lebih tepat sehingga dapat mengurangi kesalahan dalam menjumlahkan seluruh biaya.

Penerapan aplikasi harga pokok produksi yang terkomputerisasi pada perusahaan Meudang Perkasa Furniture berjalan dengan baik sehingga dapat menyelesaikan masalah terkait penetapan harga pokok produksi. Masalah yang terkait dengan keakuratan laporan juga dapat teratasi dengan baik, sehingga pelaporan yang ada pada perusahaan menjadi lebih tepat, akurat, dan realtime.

3.1

\section{Kesimpulan, Keterbatasan, dan Saran Kesimpulan}

Setelah melakukan pembahasan, perancangan dan implementasi aplikasi pada Meudang Perkasa Furniture, maka penulis dapat menarik beberapa kesimpulan sebagai berikut:

1) Perancangan sistem informasi perhitungan harga pokok produksi pada Meudang Perkasa Furniture menghasilkan sistem perhitungan harga pokok produksi yang lebih baik untuk digunakan oleh perusahaan

2) Perancangan sistem informasi perhitungan harga pokok produksi yang dirancang oleh penulis menggunakan Microsoft Access yang dapat memudahkan pengolahan data dan mempercepat dalam membuat laporan yang berhubungan dengan harga pokok produksi

3) Perhitungan harga pokok produksi yang terdapat pada Meudang Perkasa Furniture adalah jumlah biaya yang terdiri dari biaya bahan baku langsung, tenaga kerja langsung dan biaya overhead pabrik dibagi dengan total unit yang diproduksi kemudian dapat diperoleh harga pokok produksi

4) Dalam sistem ini, pengguna sistem tidak lagi memerlukan waktu yang lama untuk menetapkan harga pokok produksinya, dikarenakan sistem yang dirancang mampu menampilkan harga pokok produksi secara otomatis

\section{Keterbatasan}

Perancangan ini dibuat hanya untuk menghitung serta mengetahui perhitungan harga pokok produksi yang terdapat pada Meudang Perkasa Furniture. Hal ini disebabkan oleh keterbatasan waktu serta keilmuan mengenai perancangan suatu aplikasi yang dimiliki oleh penulis. Perancangan aplikasi ini menggunakan perangkat lunak Microsoft Access yang merupakan perangkat lunak perancangan dan pemrosesan basis data yang tergolong sederhana. Oleh karena keterbatasan yang telah disebut, maka penulis mendapatkan hambatan dalam membuat table, membuat query, mendesain tampilan form, serta mendesain tampilan report, dan membutuhkan bantuan pihak yang ahli dalam penggunaan perangkat lunak Microsoft Access guna menjalankan aplikasi yang sesuai dengan tujuan yang telah ditentukan.

\section{Saran}

1. Dengan adanya sistem perhitungan harga pokok produksi ini, penulis mengharapkan agar Meudang Perkasa Furniture dapat menerapkan sistem yang telah dirancang oleh penulis, sehingga akan sangat membantu dalam menentukan harga pokok produksinya dan dapat menghasilkan data yang tepat serta akurat.

2. Aplikasi ini diharapkan dapat dikembangkan lagi menjadi aplikasi yang lebih rumit serta mampu meningkatkan kapasitas penyimpanan datanya.

3. Penulis berharap dengan telah dilakukannya pelatihan yang diberikan oleh penulis maka pengguna aplikasi dapat menjadi tenaga ahli yang mengerti sistem ini, sehingga apabila terjadi permasalahan dapat dengan mudah diatasi.

\section{Daftar Pustaka}

Bodnar, G. H., \& Hopwood, W. S. (2010). Accounting Information Systems (10th ed.). London: Pearson Education Limited.

Carter, W. K., \& Usry, M. F. (2009). Akuntansi Biaya II (14th ed.). Jakarta: Salemba Empat.

Davis, G. B. (2013). Kerangka Dasar Sistem Informasi Manajemen. Palembang: Maxikom.

Diana, A., \& Setiawati, L. (2011). Sistem Informasi Akuntansi: Perancangan, Prosedur dan Penerapan (1st ed.). Yogyakarta: ANDI. 
Handojo, A., Purnama, C., Kristian, E. (2013). Aplikasi Perhitungan Harga Pokok Produksi Pada Peternakan Ayam Potong Panorama Dengan Metode Job Order Costing, Vol 2013(semnasIF), 50-55.

Horngren, C. T. (2008). Management and Cost Accounting (4th ed.). New Jersey: Pearson Education Limited.

Kartadinata, A. (2008). Teori Akuntansi (2nd ed.). Jakarta: PT. Gelora Aksara Pratama.

Mulyadi. (2015). Akuntansi Biaya (5th ed.). Yogyakarta: UPP STIM. YKPN.

Nafarin, M. (2009). Penganggaran Perusahaan. Jakarta: Salemba Empat.

Nahlah, \& Amirudin. (2015). Sistem Informasi Perpustakaan Berbasis Ms Access pada Jurusan Administrasi Niaga Politeknik Negeri Ujung Pandang. Jurnal Sainsmat, September 2015, Halaman 175-195 ISSN 2086-6755, IV(2), 175195.

Rama, D. V, \& Jones, F. L. (2008). Accounting Information System (1st ed.). Jakarta: Salemba Empat.

Romney, M. B., \& Steinbart, P. J. (2014). Accounting Information Systems (13th ed.). London: Pearson Education Limited.

Santoso, H. (2010). Aplikasi Web VB.NET/ASP.NET + $C D$. Jakarta: PT. Elex Media Komputindo.

Sofian, M., \& Tumiran. (2015). Aplikasi Desktop Perhitungan Biaya Pembuatan Gerobak Alumunium CV. Mitra Alumunium, 5(2).

Suarna, N. (2008). Microsoft Office Access 2007. Bandung: Yrama Widya.

Sutabri, T. (2012). Analisis Sistem Informasi. Yogyakarta: ANDI.

Winarno, E., Zaki, A., \& SmithDev. (2014). Pemrograman Web Berbasis HTML5, PHP, dan JavaScript (3rd ed.). Jakarta: PT. Elex Media Komputindo. 